Tyndale Bulletin 71.2 (2020) 207-227

\title{
DATING LUKE-ACTS \\ FURTHER ARGUMENTS FOR AN EARLY DATE
}

\author{
David Seccombe \\ (dseccombe@icloud.com)
}

\begin{abstract}
Summary
Alexander Mittelstaedt (2005) has provided new impetus to a longstanding opinion that Luke-Acts was written in the early $60 \mathrm{~s}$ of the first century AD. Karl L. Armstrong (2017) provides a recent overview of the dating debate and argues that an early date makes best sense of the extensive evidence. This paper suggests three considerations arising from the historical character of the rest of the century which support Mittelstaedt's and Armstrong's view. The first: AD 66-98 was a time of intense anti-Jewish sentiment, in which articulation of the nationalistic Jewish hopes expressed in the third Gospel and Acts would have been dangerous, and unlikely for a careful author. Second, it was also a time that ill accords with Acts' assumption of Jewish legitimacy and its plea for the acceptance of Gentile Christianity. Third, the attention given to the voyage as Acts draws to its conclusion bespeaks an author who knew nothing of the cataclysmic avalanche of events that took place from $A D$ $62-70$.
\end{abstract}

\section{The Search for Historical Context}

The absence of proven quotations or allusions to Acts prior to the time of Irenaeus made it possible in the mid-nineteenth century for F. C. Baur and the Tübingen School to propound a second-century date. ${ }^{1}$ A mass of scholarly reaction to the Tübingen hypothesis advanced a range of

1 Horton Harris, The Tübingen School (Leicester: Apollos, 1990): 181-97; William Sanger Campbell, The 'We' Passages in Luke-Acts (Atlanta: SBL, 2007): 5. 
considerations and soon repositioned Luke-Acts in the first century. ${ }^{2} \mathrm{By}$ the end of the twentieth century few still plumped for a second-century date. ${ }^{3}$ Scholarly opinion in the twentieth century largely settled into three camps: the early 60s, shortly after the end of Paul's first Roman imprisonment; ${ }^{4}$ the 70 s and 80 s (roughly speaking), after the JewishRoman war and before Domitian's persecution, the author being a former companion of Paul; 5 this latter period, but authored by a 'Paulinist', whose account is removed from the real Paul. ${ }^{6}$ The present century has brought with it a new push for a second-century dating. ${ }^{7}$

A majority of scholars favour a date between 70 and the early 90 s primarily, I think, because of a difficulty with dating Mark early enough to allow a 60 s date for Luke. For example, Craig S. Keener's monumental commentary on Acts sets out a case in some detail for placing Acts between the end of the Jewish-Roman war and Domitian's reign, most likely (he thinks) about AD 75: 'my best guesses ... are in the early $70 \mathrm{~s}$, with dates in the $80 \mathrm{~s}$ and $60 \mathrm{~s}$ still plausible, and a date in the 90 s not impossible'. ${ }^{8}$

2 For an overview of fifty years of scholarly reaction to the Tübingen position see W. Ward Gasque, A History of the Criticism of the Acts of the Apostles (Grand Rapids: Eerdmans, 1975): 53-72, 96-135.

3 Two who did: J. C. O'Neill, The Theology of Acts in its Historical Setting (London: SPCK, 1961); John T. Townsend, 'The Date of Luke-Acts' in New Perspectives from the Society of Biblical Literature Seminar, ed. Charles H. Talbert (New York: Crossroad, 1984): 47-62.

4 R. B. Rackham, The Acts of the Apostles (London: Methuen, 1901): 1-lv; Adolf Harnack, Luke the Physician (London: Williams \& Norgate, 1907); Adolf Harnack, The Acts of the Apostles (London: Williams \& Norgate, 1909); Adolf Harnack, The Date of the Acts and of the Synoptic Gospels (London: Williams \& Norgate, 1911); A. J. Matill, 'The Date and Purpose of Luke-Acts: Rackham Reconsidered', CBQ 40 (1978): 335-50; John A. T. Robinson, Redating the New Testament (London: SCM, 1976).

5 E.g. John Nolland, Luke 1-9:20 (WBC 35A; Dallas: Word, 1989): xxxvii-xxxviv; F. F. Bruce, The Book of Acts (Rev. edn; Grand Rapids: Eerdmans, 1988): 10-12; F. F. Bruce, The Acts of the Apostles: The Greek Text with Introduction and Commentary ( $3^{\text {rd }}$ edn; Leicester: Apollos, 1990): 1-18; Joseph A. Fitzmyer, The Acts of the Apostles (New York: Doubleday, 1998): 53-57.

6 Philipp Vielhauer, 'On the "Paulinism" of Acts' in Studies in Luke-Acts, ed. L. E. Keck and J. E. Martyn (London: SPCK, 1968): 33-50. Vielhauer's position has received added authority from the commentary of Ernst Haenchen, The Acts of the Apostles (tr. B. Noble, G. Shinn, and R. McL. Wilson; Oxford: Blackwell, 1971): 112-16.

7 Richard I. Pervo, Dating Acts: Between the Apologists and the Evangelists (Santa Rosa: Polebridge, 2006); Joseph B. Tyson, Marcion and Luke-Acts (Columbia: University of South Carolina, 2006); Laura Nasrallah, 'The Acts of the Apostles, Greek Cities and Hadrian's Panhellenion', JBL 127 (2008): 533-66.

8 Craig S. Keener, Acts: An Exegetical Commentary, vol. 1 (4 vols.; Grand Rapids: Baker Academic, 2012): 400. 
The question continues to be important, critical as it is to New Testament history. Literary critics, too, frequently seek to read Luke and Acts against a supposed historical background, and discussions of purpose try to locate Luke's writings in a historical context. ${ }^{9}$ The advantage to critics of belonging to a dominant school of thought is that they can proceed without the need to defend their supposed datings (at least, this is true for those holding to the later first-century date). A recent introduction to the Gospels, intended for students, locates them all in the post-70 period, as though this were established fact, and mentions no other possibility. ${ }^{10}$ Some members of the new second-century 'school' also feel they have proven their case and can proceed without argument. Given he has written a monograph defending his view, Pervo's commentary on Acts dismisses the question of date in a sentence, as though his own position were now the established orthodoxy. ${ }^{11}$

Scholars convinced of the early date felt (and feel) the need to defend it because they are a minority, and also because they feel much of importance hangs on it. Minority or not, there is a respectable tradition of critical scholarship which backs an early date. ${ }^{12}$ My own interest in the question originated at a debate between J. A. T. Robinson, following the publication of his Redating the New Testament, and Morna Hooker, shortly after her arrival in Cambridge as Lady Margaret's Professor of Divinity. ${ }^{13}$ Until then I had accepted as established fact what I had been taught: that Mark was written during the Neronian persecution, and that Luke was therefore unlikely to have been written before AD 70. At one point in the discussion Robinson asked Hooker whether she could give

9 E.g. Robert Maddox, The Purpose of Luke-Acts (Edinburgh: T\&T Clark, 1982): esp. 180-87 situates it in relation to the expulsion of Christians from synagogues in the late first century. The question of historical provenance is not always avoided by those who circumvent the pursuit of a historical Sitz im Leben and attend to Luke-Acts purely as literature, e.g. Mikeal C. Parsons, Acts (Grand Rapids: Baker, 2008): 290-95; at various points the narrative is elucidated from conditions in the early second century.

10 Warren Carter, Telling Tales about Jesus (Minneapolis: Fortress, 2016): 26-29. Note the way Daniel Marguerat assumes a date in the 80s and reads Acts in that light in his The First Christian Historian (Cambridge: CUP, 2002): 228-29.

11 'Acts was written c. 115 by an anonymous author whose perspective was that of Ephesus or its general environs.' Richard Pervo, Acts: A Commentary (Hermeneia; Minneapolis: Fortress, 2009): 5. This position is taken as a starting point, at least for Acts, by Parsons, Acts, 16, so it may be in order to call this an emerging school of thought.

12 See the impressive list of authorities holding to a pre-70 date in Karl L. Armstrong, 'A New Plea for an Early Date of Acts', Journal of Greco-Roman Christianity and Judaism 13 (2017): 98-99.

13 The debate took place in Cambridge in about 1977. 
one solid reason why Mark could not have been written in the 50s. She could not.

I do not intend to discuss the evidence for the later (post-70) firstcentury dating of Acts. It is the majority view, long-established, supported by a wide range of arguments. ${ }^{14}$ Nor can I here present my own reasons for rejecting the new arguments for a second-century date. The studies of Pervo and Tyson have been well summarised in a review by F. Scott Spencer ${ }^{15}$ and subjected to a critical treatment in Keener's discussion of a possible second-century date. ${ }^{16}$ I agree with Keener that a first-century date 'should be regarded as secure'. ${ }^{17}$

\section{Proponents of an Early Date}

In 1899 in the first issue of the Journal for Theological Studies R. B. Rackham put forward a case for dating Acts in the early 60s. ${ }^{18}$ In 1901 he summarised his argument in the introduction to what became the major English commentary on Acts ${ }^{19}$ until the appearance of F. F. Bruce's two commentaries on the Greek and English texts in 1951 and $1954 .{ }^{20}$

In three books written between 1906 and 1911 Adolf Harnack developed the view - as unpopular in Germany then as it is today - that the author of the third Gospel and Acts was Luke, the companion of Paul. In the first book Harnack judged Luke and Acts to have been written in the $80 \mathrm{~s}$. In the second he continued with the same (standard) view, but ventured the possibility that it could have been as early as the $60 \mathrm{~s}$, before the Jewish War. In the third - convinced that this was in fact the case he argued for the latter in detail. ${ }^{21}$ For anyone familiar with the debates of the twentieth and twenty-first century it is fascinating to observe Harnack convincingly countering arguments for the later dating of Luke,

\footnotetext{
14 Recently Keener, Acts, vol. 1, 383-401 summarises the debate and gives reasons for thinking Acts was written about AD 75.

15 In Interpretation 62 (2008): 190-93.

16 Keener, Acts, vol. 1, 395-400.

17 Keener, Acts, vol. 1, 401.

18 R. B. Rackham, 'The Acts of the Apostles: A Plea for an Early Date', JTS 1 (1899): 76-87.

19 Rackham, Acts of the Apostles, 1-lv.

20 Bruce, Book of Acts, 10-12; Bruce, The Acts of the Apostles, 1-18.

21 Harnack, Luke the Physician, 152; Harnack, Acts of the Apostles, 290-94; Harnack, Date of the Acts, 90-124.
} 
which are still commonplace in our own time. He was largely ignored in his own country, where opinion continued to solidify around a date in the $80 \mathrm{~s}$.

However, proponents of the early date continued to raise their heads: B. Reicke (1972), J. A. T. Robinson (1976), and A. J. Matill Jr (1978) each argued for a date in the early $60 \mathrm{~s}^{22}$ More recently, Colin Hemer (1990) cautiously weighed in for the early date, ${ }^{23}$ and now Alexander Mittelstaedt (2005) has reopened the question in Germany with probably the most thorough enquiry since Harnack's. ${ }^{24}$ Mittelstaedt looks in detail at the question of authorship, the references to the destruction of Jerusalem, the dating of Mark and Q, indications of temporal proximity to some of the events in Acts, and more. He mounts a strong case for a date in the early $60 \mathrm{~s}$, which I find convincing for the most part. Most recently, Karl L. Armstrong has reviewed the argument once more and come down in favour of an early date. ${ }^{25}$ What I wish to do for the remainder of this article is make three further observations which weigh against a date later than $\mathrm{AD} 64$, and which therefore support the argument of Mittelstaedt and others. The first is of a historical-contextual nature, arising from the likely effect of the Jewish War on Romans and other non-Jews and the need of an author to be sensitive to the danger his writing might pose to himself and other Christians.

\section{Political Inappropriateness}

From AD 66 a period of intense anti-Jewish sentiment prevailed throughout the empire. Reports of the rebellion in Judaea gave immediate pretext for the release of pent-up hostility towards Jews in the surrounding cities and countries. There were massacres in Damascus, Caesarea, Syria, Scythopolis, Ascalon, and elsewhere. ${ }^{26}$ Josephus says 50,000 Jews were slaughtered in Alexandria. ${ }^{27}$ Attacks were evidently

22 Bo Reicke, The Roots of the Synoptic Gospels (Philadelphia: Fortress, 1986): 174-80; Robinson, Redating the New Testament; Matill, 'Rackham Reconsidered'.

${ }^{23}$ Colin J. Hemer, The Book of Acts in the Setting of Hellenistic History (Winona Lake: Eisenbrauns, 1990): 365-410.

${ }^{24}$ Alexander Mittelstaedt, Lukas als Historiker: Zur Datierung des lukanischen Doppelwerkes (Tübingen: Franke, 2006).

25 Armstrong, 'A New Plea'.

26 Josephus, B.J. 2.457, 461-65, 466, 477-80, 559.

27 Josephus, B.J. 2.487-98. 
widespread, for he mentions three cities where massacres did not take place. ${ }^{28}$

This was early in the war; one wonders what it was like in the years following, and closer to Rome, and how long it continued. Titus celebrated his victory in various cities by spectacles in which Jewish prisoners were exposed to wild animals and forced to fight gladiator battles with each other. ${ }^{29}$ Diaspora Jews were not directly implicated in the war, but it must have added to the ever-present tension between Jews and other citizens. It could not have been an easy time for Jews for the remainder of the first century. Innocent or not, diaspora Jews were not exempted from paying the punitive new Jewish tax. Though New Testament scholars are fond of locating documents in this period, AD 70-100 is actually something of a black hole in Jewish history: 'The sources are almost completely silent about events between the first and second revolts. ${ }^{30}$ What evidence there is speaks of subjugation and depression. We know of massacres of Jews after the war as far away as Cyrene (Libya) and of ongoing maltreatment encouraged by an imperial attitude that Jews should pay for what they had cost the empire. ${ }^{31}$ Mary Smallwood sums up the evidence of periodic police round-ups of members of the house of David:

28 Josephus, B.J. 2.479.

29 Fergus Millar, The Roman Near East 31 BC-AD 337 (London and Cambridge, Mass.: Harvard University Press, 1993): 78-79.

30 J. Alberto Soggin, The History of Israel and Judah ( $3^{\text {rd }}$ edn; London: SCM, 1998): 380. See also Peter Schäfer's study of Jewish history in the Greco-Roman world. He discusses only the reorganisation of Palestine as an independent Roman province, and the rise of the rabbinate and Jamnia (the only significant 'event'), before jumping to the uprisings of AD 115: Peter Schäfer, The History of the Jews in the Greco-Roman World (London and New York: Routledge, 2003): 131-43. Appelbaum deals with the period in four lines: Shimon Appelbaum, Judaea in Hellenistic and Roman Times (Leiden: Brill, 1989): 157. Mary Smallwood, The Jews under Roman Rule (Leiden: Brill, 1976): 33188 has a much more substantial discussion, but admits the paucity of information; e.g. 'there is no continuous history of Palestine after 70' (p. 331). Eck's study of the Roman army in Palestine (Werner Eck, Rom und Judaea (Tübingen: Mohr Siebeck, 2007): 11645) has little to say of the period that interests us. He provides more information about the period of the Bar Kokhba rebellion in AD 132-136.

31 Allen Kerkeslager, 'The Diaspora from 66 to c. 235 CE: The Jews in Egypt and Cyrenaica, 66-c. 235 CE' in The Cambridge History of Judaism, ed. S. Katz (Cambridge: CUP, 2006): 53-67, esp. 55. Eck, Rom und Judaea, 112 mentions a Roman consul of Judaea in Trajan's reign, known in Jewish sources as 'Judenschlächter' ('Butcher of Jews'). 
for at least thirty years [after 70] the Romans were on the alert to guard against incipient messianic movements and to pounce on anyone who looked like a potential trouble-maker. ${ }^{32}$

A first-century reader of Luke or Acts would see them as Jewish writings and the author as the proponent of an essentially Jewish movement, albeit one that sought to recruit Gentiles. If the author were writing after AD 66 he would need, therefore, to exercise considerable caution in relation to anything that might be deemed political or revolutionary, considering the fact that his writings might fall into the hands of, or be heard by, parties hostile to the Christian movement. In this regard, it is hard to imagine anything more inflammatory than the first two chapters of Luke. The story is about the coming of a Jewish king who will scatter the 'arrogant' (a common Jewish designation of Romans and former Gentile overlords) ${ }^{33}$ bring down rulers, and lift up the downtrodden of Israel. He will rescue the Jews from those who hate them so they can serve their God without fear. ${ }^{34} \mathrm{He}$ has come for the 'consolation of Israel' and the 'redemption of Jerusalem', ${ }^{35}$ Old Testament expressions which, one suspects, could have had some currency amongst the revolutionaries. Most of the story is set in the temple, one day to become the headquarters of the war against Rome. Christian readers tend to spiritualise this militant political language, ${ }^{36}$ but it is difficult to see how such an account could have been published or owned for many decades after AD 66 without considerable risk. To give the new-born child the titles 'Saviour' and 'Lord' - both titles of the reigning emperor - was daring at any time, but needlessly provocative for an author and his movement for decades after AD 66. Even more dangerous would be Luke's unwitting detail that one of Jesus's disciples was a Zealot. ${ }^{37}$ It was the Zealots who were blamed for the war. However, prior to the outbreak of war, these features of Luke need not have caused such offence, and would have commended his work to Jewish readers. ${ }^{38}$

32 Smallwood, The Jews, 352.

33 Luke 1:51-52; Pss. Sol. 2.17; Tg. Yer. I Exod. 15:1,21; Rom. 1:30.

34 Luke $1: 71,73$.

35 Luke 2:25,38.

36 I. Howard Marshall, 'Political and Eschatological Language in Luke' in Reading Luke, ed. Craig G. Bartholomew et al. (Milton Keynes: Paternoster and Grand Rapids: Zondervan, 2005): 157-77 argues for a metaphorical reading, but Luke doesn't make this obvious.

37 Luke 6:15.

38 Scholars disagree on whether Luke-Acts is intended for Jewish or Gentile audiences. I am personally convinced that both are intended, and that one of Luke's purposes is to 
The same argument applies to the period following the Jewish uprisings of $A D 115$ and 132. In fact, there is an almost unbroken period stretching from AD 66-150 where Jewish nationalist sentiments would have been dangerous. Regardless of what comes later in the story, the author could be understood by a non-Christian reader to champion the revolution which the first two chapters of Luke promise.

Admittedly, this only works as an argument for dating Acts if we see Luke and Acts belonging together and close in time. Since Cadbury's ground-breaking classic, it has been accepted by most scholars that LukeActs is a two-volume unit in the sense that the author intended both from the outset; ${ }^{39}$ however, this has been challenged. ${ }^{40}$ In any case, that they are both addressed to the same Theophilus suggests that Luke intended that they be read (heard) together and that they proclaim a unified message. Does Acts, then, have anything of the Jewish nationalist flavour apparent in the early chapters of the Gospel?

Acts begins with the disciples' question about when the 'kingdom' would be restored to Israel. ${ }^{41}$ This corresponds with the seeming revolutionary promises in the Gospel prologue, so, although Acts lacks the violent metaphor of the songs of the infancy narrative, it continues to speak of a restoration of sovereignty to Israel in kingdom language that could sound treasonous if read after the revolutionary uprising of AD 6670. Christian readers are accustomed, as I said, to spiritualising such political terms, and a close study of the whole of Luke and Acts may modify any suggestion of violence, but this hardly deals with the reaction of a suspicious or hostile reader in the post-war period. It might be argued that Acts casts the Roman authority in a positive light and obviates such a reading, but without some clear disclaimer or explanation, the combination of the revolutionary tone of the birth narratives, the continuity of Luke and Acts proclaimed in the prefaces, and the continuance of the motif of Israel's restored kingdom could at the least suggest sympathy with the Zealot uprising. Acts closes with Paul

persuade Jews that the full inclusion of Gentiles in the people of God, without circumcision, is in accordance with God's will.

39 Henry J. Cadbury, The Making of Luke-Acts (London: SPCK, 1968): 8-11. Paul S. Minear, 'Luke's Use of the Birth Stories' in Studies in Luke-Acts, ed. L. E. Keck and J. L. Martyn (London: SPCK, 1968): 111-30 has convinced many that Luke-Acts must be considered a literary whole.

40 Parsons, Acts, 16-17 thinks Acts was written some thirty years after the Gospel.

41 Acts 1:6, and see 3:21. There is no indication that the disciples have asked an inappropriate question, nor that Luke does not expect some kind of real fulfilment of Israel's restoration. 
declaring himself 'bound with this chain because of the hope of Israel' (28:20). These are fine words for Jewish readers before AD 66, but after a five-year war fought over this very issue, I argue they would be inflammatory and dangerous.

According to Acts, the case against Paul for his forthcoming trial in Rome was to do with his dispute with Jerusalem; there is no accusation of treason. The later trial, which resulted in his death, may have been of this nature. ${ }^{42}$ Were Acts 28:20 and Luke 1 cited in evidence in a treason trial, condemnation would be swift. If Luke had written any time after the Neronian onslaught, he would have been mindful that what he wrote might be so used against himself, Theophilus, or other members of his movement.

Luke clearly intended his work primarily to be read and heard by Christians. ${ }^{43}$ I do not think he was writing for Roman outsiders. His purpose, judging by his major themes, was manifold. He reinforces an understanding of who Jesus is and what he was like and develops the nature of Jesus's salvation mission - how he executed it, and its outcome. He teaches on discipleship, and a large part of Luke is devoted to issues of Christian life. In Acts he continues to answer the question of who Jesus is and describes evangelism in various contexts. He mounts an apology for the new entity, the church, defends the admission of Gentiles on an equal footing to Jews, and explains why circumcision is not required of Gentile converts. He outlines the course of Paul's mission, and finally defends the apostle against the charges of being anti-Jewish and his teaching heretical, in the course of which he presents Christianity as the authentic continuation of God's scripturally revealed salvation plan. The relevance of all this to Christian audiences can easily be seen, as can its value as an apology towards Jews. Thus, I am not arguing for any intention on Luke's part to address pagan outsiders; rather, I am raising the possibility of unintended consequences. Someone in the post-war

42 See the discussion in Harry J. Tajra, The Martyrdom of St. Paul (Eugene: Wipf \& Stock, 1994): 76. He argues that Paul's history in Rome must be seen in terms of two terms of imprisonment, the second being on a charge of 'crimen laesae majestatis'. Regarding the first imprisonment, Brian Rapske, The Book of Acts and Paul in Roman Custody, vol. 3 of The Book of Acts in its First Century Setting, ed. Bruce W. Winter (Grand Rapids: Eerdmans, 1994): 191 thinks the conditions of Paul's first custody indicate a Roman estimate that he would be released.

43 E.g. Marguerat, The First Christian Historian, 23-24. He puts weight on the repetition of the first-person plural in Luke 1:1,2, suggesting 'a common adherence to a tradition' and the establishment of a 'reading community', unparalleled in Graeco-Roman history writing. 
period (even after AD 64) writing about a predominantly Jewish (or Christian) movement would know he must be careful; a book can be read by anyone, and will be, in a climate of suspicion. This is presumably one reason for the apocalyptic 'code' of the book of Revelation.

I conclude therefore that both Luke and Acts were probably written before the Jewish-Roman War and Nero's pogrom. From AD 64 until the end of the century and later, the third Gospel or Acts would have been dangerous books to have in one's possession. This is a possible reason for their not having had wide circulation before the second century.

I would add a small point related to the way Acts ends. To my knowledge, little attention has been paid to the way Paul's detention might appear to unfriendly readers in the latter part of the century. Most commentators are convinced that Luke wishes to portray Paul (and Christianity) as innocent as far as the Roman state was concerned. This is probably correct. But why then does Luke leave the outcome of the trial undetermined? If one of his intentions was to highlight the innocence of Christians, if he wrote when suspicions ran high, and if he anticipated his writing falling into the wrong hands, he would hardly omit some indication of an outcome in Paul's favour - either an acquittal or a discharge. ${ }^{44}$ Otherwise he invites a presumption of guilt. This is a lot of 'ifs', but these are likely considerations for a careful writer. ${ }^{45}$ It is all very well to suggest a literary conclusion dovetailing with an outcome which must have been common knowledge among Christians, but this hardly works with an author who is mindful of hostile readers. If he wrote before all the turmoil of AD 64-70, however, Luke's silence is explicable because he had reached the end of his knowledge, because he expected his readers to complete the story from their own information, or for some other literary reason.

\section{An Apologia for Gentile Christianity}

My second observation arises from the likely effect of the war on Christians and Jews. Luke's argument in Acts hardly fits the conditions

\footnotetext{
44 Tajra, Martyrdom, 46-47, 50 argues that Luke's mention of a 'biennium' indicates the closure of the period set for accusers to bring forward their case; Luke hints that Paul was released. Hemer, Acts, 390-404 inclines to Paul actually facing trial and being acquitted.

45 If Paul was condemned prior to Nero's pogrom, a different kind of defence would be required, but the evidence is against this.
} 
of Christians vis-à-vis Jews in the post-AD 70 period. Elsewhere I have argued that Luke-Acts was written at a time when church and synagogue stood opposed. Luke's work is in part an apology for the church and its inclusion of Gentiles, written when the synagogue was in an ascendant position. ${ }^{46}$ Among other things, this is evident in the way the word 'church' ( $\dot{\varepsilon} \kappa \kappa \lambda \eta \sigma i ́ \alpha)$ is introduced and defined (Acts 7:38), the accusation of its being a sect rejected (Acts 24:14), and the care with which Gentile Christianity is introduced in the Cornelius story, with Peter, not Paul, as its initiator (Acts 10:1-11:26). My second objection to a later date, therefore, arises from the nature of Acts, which, whatever other purposes it had, clearly included an apology for the admission of Gentiles among the people of God. ${ }^{47}$ The need for such an argument after the war is questionable.

Some argue that the church continued to be beholden to the synagogue after the war, so the need to defend its inclusion of Gentiles remained. J. Louis Martyn proposed that the prayer cursing sectaries, introduced into the synagogue liturgy in Judaea sometime in the $90 \mathrm{~s},{ }^{48}$ was directed at Christians, and posed a serious threat. Both Maddox and Esler situate the writing of Acts at about this time to answer this alleged crisis. ${ }^{49} \mathrm{We}$ should consider, however, that there was no coercive authority in Jewry at this time. From a Roman point of view, the destruction of the Jerusalem temple and the cessation of its cult meant the end of Jewish religion $^{50}$ (though Jews did not lose their legal right to practise their

46 David Seccombe, 'The New People of God' in Witness to the Gospel, ed. I. Howard Marshall and David Peterson (Grand Rapids: Eerdmans, 1998): 349-72. See also David Seccombe, 'Luke's Vision for the Church' in A Vision for the Church: Studies in Early Christian Ecclesiology, ed. Markus Bockmuehl and Michael B. Thompson (Edinburgh: T\&T Clark, 1997): 57-61. This is no novel contention; I am not aware of any scholar who argues against it, though, of course, there are many views concerning Luke's purpose. Both Maddox, The Purpose of Luke-Acts, 6-9, 183-86 and Philip F. Esler, Community and Gospel in Luke-Acts (Cambridge: CUP, 1987): 53-58 imply a strong position for the synagogue late in the century. Esler thinks Acts was written when the church was still emerging as a 'sect' of Judaism.

47 Keener, Acts, vol. 1, 161-64, following Gregory Sterling, describes Acts as 'apologetic history'. William F. Brosend, 'The Means of Absent Ends' in History, Literature and Society in the Book of Acts, ed. Ben Witherington III (Cambridge: CUP, 1996): 348-62 agrees with various scholars that 'historical monograph' is the best genre with which to group Acts, and also recognises the apologetic dimension.

48 J. Louis Martyn, History and Theology in the Fourth Gospel (Louisville: John Knox, 2003): 56-66.

49 Maddox, The Purpose of Luke-Acts, 183-84 and Esler, Community and Gospel, 2729.

50 Seth Schwartz, 'Political, Social and Economic Life in the Land of Israel 66-c.235' in The Cambridge History of Judaism, ed. S. Katz (Cambridge: CUP, 2006): 23-52, esp. 
distinct way of life). Judaea was annexed as a province of the Roman Empire. Unlike the previous 160 years of Roman rule, when Jewish leadership, institutions, and law were respected and kept intact, Jews in Judaea were now ruled by Roman officials according to Roman law. ${ }^{51}$ There is scant evidence of a Jewish political leader being recognised by Rome in the next hundred years, and perhaps longer. ${ }^{52}$ Vespasian levied a two-drachma tax on every Jew in Judaea and throughout the empire, and the fiscus Judaicus was established to collect the tax. What formerly had been the right of Jews to remit gifts to the temple in Jerusalem was replaced by a humiliating licence to be a Jew, the proceeds of which went to the upkeep of a pagan temple. I have already said that no distinction was made between those who took part in the war and diaspora Jews who remained loyal to the empire. ${ }^{53}$

Ill treatment continued into the reign of Domitian (AD 81-96). Suetonius writes: 'I recall being present in my youth when the person of a man ninety years old was examined before the procurator and a very crowded court, to see whether he was circumcised. ${ }^{54}$ The severity of the Jews' plight may be judged from the fact that the new emperor, Nerva (AD 96-98), put a stop to denunciations of Jews for not paying the Jewish tax and struck a coin to celebrate the reform. ${ }^{55}$ However, his successor, Trajan, did not continue his protectiveness, and Jewish frustrations boiled over into new revolts in AD 115 and again in 132. Thus, it is doubtful that there was any period between 70 and 140 when being a Jew was not a handicap.

30. In AD 73 the Romans also closed the Jewish temple in Leontopolis in Egypt (Kerkeslager et al., 'Diaspora', 55).

51 Schwartz, 'Political', 25-28. For another view see Appelbaum, Judaea, 164.

52 Smallwood, The Jews, 349 thinks the Romans treated the ruler of the Jamnia school as a legitimate authority, but this is disputed (Schwartz, 'Political', 27-28). According to Shaye J. D. Cohen, From the Maccabees to the Mishnah (Philadelphia: Westminster Press, 1987), 221-22 only at the end of the second century was the head of the rabbinic academy recognised by the Roman government as 'leader of the Jews in Palestine'. Schürer cites Origen's reference to secret trials carried out by the 'ethnarch' of his time (early third century) as evidence for some measure of eventual toleration of the practice of Jewish law in Palestine after AD 70, but practice in Origen's time is unlikely to reflect that of the immediate post-war situation. Emil Schürer, The History of the Jewish People in the Age of Jesus Christ (175 B.C.-A.D. 135) Vol.1., ed. Geza Vermes et al. (Edinburgh: T\&T Clark, 1973): 526.

53 Smallwood, The Jews, 374 speaks of 'a psychological burden, marking them out as members of a defeated race punished for their nationality'.

54 Suetonius, Dom. 12.2, tr. J. C. Rolfe (LCL 38; Cambridge, Mass.: Harvard University Press, 1914).)

55 Schwartz, 'Political', 32. 
Thus, Martyn's proposal seems an unlikely guess. The Birkat Haminim, if it had anything to do with Christians, was more likely a reaction to their successful proselytising than anything that could have harmed them. One wonders what motive Christians might have had to cling to the synagogue in a general climate of anti-Judaism, when there was a real danger one might be denounced as a Judaist and required to pay the tax. Ramifications of a local kind with regard to synagogue expulsion are possible, but these could hardly have had much effect in the Diaspora. ${ }^{56}$ Evidence that Christians in the post-war period clung to the synagogue, and feared expulsion, is lacking.

It could be countered that despite the feeling against Jews, their right to live in their own way was recognised by the state and their gatherings were lawful. Christians would then have been obliged to stick close to them, regardless of their unpopularity. In the first century, Christian meetings were easily viewed as a form of Jewish gathering, albeit sectarian. Did they continue to shelter behind the synagogue after the war? The New Testament writings bear abundant testimony to Christians meeting without restriction in many places. There is no indication of a need for the protection of the synagogue. Nero's attack in AD 64 identified Christians as a distinct movement, but this does not appear to have resulted in later proscription of their meetings. Well into the second century the writings of Ignatius evidence Christians meeting in cities of Asia with no indication of dependence on a quasi-Jewish identity. ${ }^{57}$ Even the younger Pliny's correspondence with Trajan reveals that Christians were meeting in Bithynia until the governor's ban. ${ }^{58}$ The fact that Christianity emerges into the second century as an independent movement suggests a much earlier departure from the synagogue. What evidence there is, therefore, suggests Christians met in the post-war period without the protection of Judaism.

Common sense insists that Jews inside and outside Judaea kept a low profile for many years after the war. Despite the fact that Jewish ideas continued to have appeal for some Gentiles, this was not a period when Judaism was self-confidently asserting itself against Christianity. Rather,

56 Cohen, Mishnah, 227-28, also 221-23.

57 Only in the letters of Ignatius to the Magnesians (8-10) and the Philadelphians (6.1; $8.2 ; 9.1-2)$ is there a warning to beware of Jewish ideas. 1 Clement contains no evidence for Rome or Corinth of restrictions on Christian meetings.

58 Pliny, Letters, 10.96-97. These Christians met on Sunday, another evidence of a distance from the synagogue. 
there is evidence of disillusionment and defection. ${ }^{59}$ In addition, the destruction of the temple would have provided powerful arguments for Christians and have further demoralised Jews. ${ }^{60}$ Josephus enjoyed imperial protection and wrote his histories in an attempt to reinstate his people. The first rabbinic writings did not appear until about AD 200.

Prior to AD 66 Christianity was a predominantly Jewish movement with Jewish leaders, a Jewish Bible, and Jewish theology. The main debate was around the terms of admission of Gentiles. In the years that followed, a radical change took place, for, when we emerge into the second century, we find an overwhelmingly Gentile movement. It is not hard to see the reason: apart from the short-lived persecutions of Nero and Domitian, Gentile Christians had an open field. Judaism was not such a powerful force.

Both Luke and Acts are works of Jewish history in the sense that they describe mainly Jewish events in the period AD 27-62. One does not expect much detail of the subsequent period, regardless of when they were written. Nevertheless, the case they argue and the manner in which the stories are told betray something of the author's time, and it is neither 70-100 nor the first half of the second century. An inspection of Acts reveals an intense concern for the legitimacy of the mission to Gentiles and for Paul as its main protagonist. Chapters 10-11 are devoted to proving that the mission was initiated by God through Peter, and that it entailed an acceptance of Gentiles as clean, with consequent willingness to visit their homes and eat with them. Chapter 15 establishes that circumcision is not to be required of Gentiles as a condition of salvation and membership of the people of God. Many chapters $(9: 1-30 ; 13: 1-$ $14: 28 ; 15: 22-28: 31)$ are given to Paul's mission and to showing that his ministry was initiated by God, led by God, and therefore representative of true Christianity. The shape of the argument presupposes that Jews were in the position of power vis-à-vis Gentile Christians, whom they are being asked to accommodate. Jews are predominant in the synagogue and the church, secure in their identity as the people of God; Luke wanted them to acknowledge that God was doing a new thing with the Gentiles, who stood formerly in an inferior position as regards membership of the

\footnotetext{
59 Schwartz, 'Political', 29-30.

60 There is no hint of this in Acts, one of the factors that has convinced some that it was written earlier. See J. A. T. Robinson, Redating, 90-91. Acts deals with the Christian story up to about $\mathrm{AD} 62$, so it can be argued there was no place for mention of the temple's demise. However, Robinson notes that Jesus predicts it, or predictions are placed in his mouth, so one could expect something similar in Acts.
} 
divine commonwealth. Such an argument ill befits the period after AD 70. It dovetails with what we know of the 50 s and early 60 s. $^{61}$

\section{A Momentous Decade}

My third consideration is a repackaging of Rackham and Hemer and relates to the effect of events of the $60 \mathrm{~s}$ and $70 \mathrm{~s}$ on the author of Acts. AD 62-71 was a momentous decade for Christians, Romans, and Jews. In 62 Festus died in Judaea, and in the interregnum, before the new prefect arrived, the high priest, Ananus, seized the opportunity to put James, the brother of Jesus, on trial, and executed him by stoning. ${ }^{62}$ Related, no doubt, to the wave of Jewish nationalism which would climax in the war, this event caused a furore at the time, and led King Agrippa II to depose Ananus from the high priesthood. ${ }^{63}$ Also about 62, there is reason to think Paul was released from Roman captivity, possibly after a trial, but perhaps through the dismissal of his case for want of accusers. ${ }^{64} \mathrm{He}$ then returned to the province of Asia, where he was involved in further ministry. ${ }^{65}$ In 64 Rome burned and Nero made scapegoats of the Christians, thereby unleashing the first attack of the

61 Contrary to the picture I am arguing, Jacob Jervell, 'The Mighty Minority' in The Unknown Paul (Minneapolis: Augsburg, 1984): 26-51 sees the period AD 70-100 as one of considerable 'Jewish Christian' influence. However, the evidence for this is drawn largely from Luke-Acts, which he dates towards the end of this period. His reconstruction of the history of this period is somewhat confusing. He holds that Jews were a dwindling minority, but asserts their dominance. He is forced to relegate the major growth of Gentile Christianity to the second century: 'Early Christianity and Acts' in The Unknown Paul, 20. I fail to see how Luke's apology for the Gentile mission would be called for, even given Jervell's position. Jervell has done a service to scholarship in drawing attention to the importance of Jewish Christianity, but appears to me to underestimate the Gentile influence in the pre- and post-70 church.

62 Josephus, A.J. 20.197-203.

63 Josephus, A.J. 20.203.

64 See Schwartz, 'Political', 29-30 and Tajra, Martyrdom, 73-76. Haenchen, Acts, 73132 thinks Luke 'presupposes' Paul's death because of the prophetic word in Acts 20:25,38. He doesn't acknowledge the possibility that these statements may be evidence that Luke did not yet know of Paul's release (if he returned to Ephesus). There is no positive evidence that Paul died prior to Nero's persecution, so a negative outcome of the first trial is unlikely.

${ }^{65}$ Simon J. Kistemaker, Acts (Grand Rapids: Baker Book House, 1990): 996; Keener, Acts, vol. 4, 3770-71 marshals the evidence. In Phil. 1:25 and Phlm. 22 Paul expects to be released. Whether or not Paul wrote it, $1 \mathrm{Tim}$. is evidence of ministry beyond the horizon of Acts. In 2 Tim. 4.6-8 Paul's death is impending. 
Roman state on Christianity. ${ }^{66}$ In 66 Jewish revolutionaries seized the temple in Jerusalem and suspended sacrifices for the emperor. ${ }^{67}$ War broke out in Judaea and Galilee. Probably towards the close of Nero's reign, Peter and Paul were executed in Rome. ${ }^{68}$ In 68 Nero was deposed and committed suicide. ${ }^{69}$ Galba, Otho, and Vespasian succeeded to the emperorship in quick succession. According to Eusebius, a large number of Christians fled to Transjordan before the investiture of Jerusalem by the Romans under the command of Titus. ${ }^{70}$ In 70 Jerusalem was captured after a six-month siege. ${ }^{71}$ The temple was destroyed by fire. ${ }^{72}$ In 71 Vespasian and Titus celebrated their triumph in Rome and the surviving Jewish revolutionary leader was executed. ${ }^{73}$

That there is neither mention nor hint of any of this in Acts is regarded by Rackham as compelling evidence that the book had been published beforehand: the author 'must have been a skilful writer not to let even a hint of these things escape him' ${ }^{74}$ Arguments from silence are notoriously difficult, but given the subject matter and argument of Acts, its silence at least on the death of James, the outcome of Paul's trial, and the destruction of the temple is hard to account for, if Luke knew of them. ${ }^{75}$ But can we not make something more of this than an argument from silence?

66 Tacitus, Annals 15-16; for discussion, Paul Barnett, Jesus and the Rise of Early Christianity (Downers Grove: IVP, 1999): 303-304.

67 Josephus, B.J. 2.408-410. See Schürer, History, vol. 1, 486.

68 In Peter's case, an inference from 1 Clem. 5 and early tradition, e.g. Mart. Ascen. Isa. 4.4 (Gk). For evidence and discussion see Oscar Cullmann, Peter: Disciple, Apostle, Martyr (London: SCM, 1953): 80-115. For Paul, Eusebius Hist. eccl. 2.22 and see Tajra, Martyrdom, esp. 12-24, 73-76.

69 T. E. J. Wiedemann, 'From Nero to Vespasian' in CAH X: The Augustan Empire 43 B.C.-A.D. 69 (Cambridge: CUP, 1996): 256-61.

70 Eusebius, Hist. eccl. 3.5.3.

71 Josephus, B.J. 5.1-6.434.

72 Josephus, B.J. 6.164-284. Mittelstaedt, Lukas, ch. 2 says the burning of the temple was the chief characteristic of Jerusalem's fall and notes that Luke makes no mention of it.

73 Josephus, B.J. 7.123-157.

74 Rackham, Acts, li. Armstrong, Acts, $94-96$ adds the interesting point that there are no textual variants or expansions of Acts 28 that betray knowledge of events of the following decade.

75 Robinson, Redating, 13-30, 88-92 sees the lack of mention of the fall of Jerusalem as reason for dating the whole New Testament prior to AD 70. With some NT books this argument from silence is not persuasive, but for Acts it is strong. 
If Acts is silent on all of this, what is it loud on, especially towards the end, where we most expect something climactic? ${ }^{76}$ The answer is the account of the ill-fated voyage on which the author - some say the implied author - accompanied Paul to Rome.

Any consideration of the voyage narrative must, of course, reckon with the possibility that it is fictional. Robbins argues that the first-person narrative is a device to heighten the impression of immediacy, ${ }^{77}$ and Pervo thinks it is part of a second-century 'novel' intended primarily to entertain its hearers, though he is doubtful it is pure fiction. ${ }^{78}$ How does one distinguish between fiction ('fictive realistic prose') ${ }^{79}$ and a narration of something that happened, given that the former seeks to create the sense of reality? On the surface, the two may look alike. Geographical and historical embeddedness takes us some way, but it seems to me the most telling factor is the homogeneity of the novel compared to the lesser number of smooth transitions in the historical narrative. However skilfully worked, the historical narrative is forced to conform to events. As Brosend, comparing Acts with ancient novels, asks, 'why so many loose ends? ${ }^{80}$ Chariton's Callirhoe, for example, tells the tale of a pair of ill-fated lovers who, after many exciting adventures, are reunited and live happily ever after. ${ }^{81}$ Each part of the story connects with what follows, one or the other of Callirhoe or Chaereas are always in the spotlight, and there is little that is extraneous to the exhausting plot. Acts, however, besides focusing on several main and lesser characters, has all the unanswered questions and loosely connected events one expects in a narrative of real happenings in a thirty-year period. The account of the voyage holds together as story better than much of Acts. We do not have

\footnotetext{
76 There has been much discussion of the last chapter and conclusion of Acts. I decline to address it here. I have touched on the subject elsewhere (Seccombe, People, 366-70).

77 Vernon K. Robbins, 'By Land and By Sea: The We-Passages and Ancient Sea Voyages' in Perspectives on Luke-Acts, ed. Charles H. Talbert (Edinburgh: T\&T Clark, 1978): 215-42.

78 Richard Pervo, Profit with Delight: The Literary Genre of the Acts of the Apostles (Philadelphia: Fortress, 1987); 10-11 states his thesis. Susan Marie Praeder, 'Luke-Acts and the Ancient Novel', SBL Papers 20 (1981): 269-92 argues that genre-wise Acts should be classified as a sub-genre of the ancient novel, though she allows for much historical material, in the manner of a historical novel, and a didactic purpose. For Pervo's affirmation of some historical basis, see Acts, 645: 'Solutions that judge this material entirely factual or completely fictitious are questionable.'

79 Stanley E. Porter, Paul in Acts (Peabody: Hendrickson, 2001): 15 points out that ancient novels are not historical novels, 'but fictive realistic prose narratives'.

80 Brosend, 'Absent Ends', 353-54.

81 Chariton, Callirhoe (LCL 481; Cambridge, Mass.: Harvard University Press, 2014).
} 
to dispute that Luke intended it to be enjoyed. It also carries forward his portrayal of Paul. As Marguerat has shown, for pagan listeners, the story establishes his innocence, and for Jews he is vindicated by the working of providence. ${ }^{82}$ But why so much detail - and circumstantial detail which largely squares with reality? Even F. C. Baur, who saw Acts as a mid-second-century creation, felt the author must have had in his hands a genuine diary of the voyage. Haenchen, who is sceptical of Luke's portrayal of Paul, nonetheless treats Acts 27 as a serious account of a real sea voyage. ${ }^{83}$ Porter presents a case for seeing it as part of a longer travel narrative, possibly from Luke, but more likely some other companion of Paul ${ }^{84}$ Leaving the portrayal of Paul to one side, there is nothing in the account of the voyage itself that betrays it as fictive, as Keener's recent serious and detailed discussion of all the elements of the story makes clear. ${ }^{85}$ To my mind, another clear indication of the author's attempt to tell a real story is the first-person narration. Pervo concurs with Robbins that Luke is following a sea voyage convention using first-person narrative to heighten excitement with a sense of immediacy; the presence of the author is not implied. ${ }^{86}$ Various scholars have refuted this. ${ }^{87}$ To the unschooled hearer, ancient or modern, the author's presence is implied. Homer, Pervo claims, establishes the 'we' style in travel narrative with 'details of time and fluctuations between persons in narration'. He cites the voyage in Odyssey 14.244-258. ${ }^{88}$ In this passage, however, and that in which it is embedded, with its skilful movement between speakers, and with first- and third-person speech, there is never any doubt about who is speaking (the narrator, Odysseus, or Eumaeus). ${ }^{89}$ Nor, in my

\footnotetext{
82 Marguerat, Historian, 216-19.

83 Haenchen, Acts, 697-716.

84 Porter, Paul in Acts, 10-46.

85 Keener, Acts, vol. 4, 3573-657.

86 Robbins, 'We-Passages', 215-42, esp. 241-42.
}

87 Colin J. Hemer, 'First Person Narrative in Acts 27-28', TynBul 36 (1985): 81-86; he examines Robbins' references and thinks they do not support his conclusion. Of the use of the first person, Hemer says: 'I contend that this is a natural tendency dictated by the natural situation, not an artificial literary device' (p. 86). See discussions in Eckhard Schnabel, Exegetical Commentary on the New Testament: Acts (Grand Rapids: Zondervan, 2012): 1030-32 and Porter, Paul in Acts, 15-24.

88 Pervo, Profit with Delight, 57. See the critique in Porter, Paul in Acts, 18-19.

89 There is a masterful movement between narrator, Odysseus (disguised as an old man just come from the sea), and Eumaeus, his former swineherd, to whom he has come for shelter. The reader, of course, knows the old man's true identity. Within the narrative, in first-person speech (reported by the narrator), the unrecognised Odysseus draws out the swineherd about his former master and suggests that perhaps he may have encountered him on his journeys and could bring news (14.115-120). Eumaeus answers, again in 
reading, is there for the listener to Acts, since the narrator has identified himself at the beginning of each of his two volumes as the friend of Theophilus. ${ }^{90}$ We should ask how Theophilus would have read the voyage story. $\mathrm{He}$, if anyone, would have known whether the author accompanied Paul..$^{91}$ If he did not, and Theophilus nevertheless acted as publisher, he was complicit in a falsehood that belies the stated intention of the first preface. I concur, therefore with those who, regardless of its literary artistry, and the degree to which it is accommodated to its theological and apologetic purpose (which are important factors), see the narrative as the experience of the author. ${ }^{92}$ Indeed, this partly explains the inclusion of the section.

Let us imagine ourselves standing with the author in AD 70-100, looking back over the events of forty to seventy years, planning a work

direct speech, that many have tried to ingratiate themselves by pretending to bring good news of Odysseus; the old stranger should not resort to such trickery to ensure a good reception (14.121-147). Then the old man (Odysseus in disguise) solemnly declares that

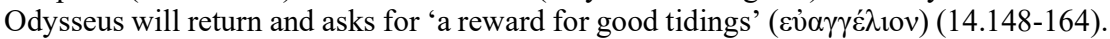
The narrator then addresses Eumaeus: 'To him then, swineherd Eumaeus, did you make answer and say ...' introducing the swineherd's direct speech to Odysseus (14.165-193). Then Odysseus continues his first-person speech, recounting his make-believe origin, and telling the tale of his misfortunes and journeys, on one of which he claims to have heard news of Odysseus (14.235-359). This includes the first-person account of the sea voyage which Pervo cites as a much-imitated style of narration. (Quotations from Homer, Odyssey, vol. II, tr. A. T. Murray, rev. George E. Dimock (LCL 105; Cambridge, Mass.: Harvard University Press, 1919).)

90 Campbell, 'We' Passages, makes much of the anonymity of Luke-Acts and the lack of any explanation of the change to first-person speech in the 'we' sections: 'The shift in grammatical person in these passages presents interpretive problems because the narrator does not provide an explanation for the change and the reason is not obvious from the narrative context' (p. 1). But surely it is. 'We' normally indicates the presence of the speaker or narrator. Only a reader's prior decision that he couldn't have been there would present a problem and demand some solution.

91 Porter, Paul in Acts, 10-46 in his careful study of the 'we' sections in Acts concludes that they were all part of a once-consecutive source; he allows that Luke may have been the author, but thinks it more likely that he was not. I fail to see his reasons for this last judgement. A competent author incorporating a first-person source will either indicate the author of the source or transpose it into the third person. Otherwise he gives the impression that he himself is speaking. The author of the third Gospel indicates his use of sources at Luke 1:2 and always indicates the speaker when he employs direct firstperson speech, e.g. Luke $1: 19-20 ; 1: 41-45 ; 1: 46-55 ; 1: 67-79 ; 2: 25-32$. Luke could no doubt have quoted something in direct speech from Anna, but transposes to the third person. This is his practice throughout the Gospel and Acts; e.g. see Acts 1:15-22; 15:6$21 ; 23: 26-30 ; 24: 1-8$.

92 Among others J. B. Lightfoot, The Acts of the Apostles: A Newly Discovered Commentary (Downers Grove: IVP Academic, 2014), 215; Bruce, Acts, 307-308, 474500; Fitzmyer, Acts, 580, 766-85; Ben Witherington III, The Acts of the Apostles (Grand Rapids: Eerdmans, 1998): 480-86, 754-82; Darrell L. Bock, Acts (Grand Rapids: Baker Academic, 2007): 13-14, 726-48; Schnabel, Acts, 39-40, 1022-57. 
of some 18,000 words that will be historical, theological, evangelistic, apologetic, and listenable. How much space will he devote to what? The account of the last voyage is one of the lengthiest sections in the book. Verse for verse, it is the least theological..$^{93}$ On the surface, it makes a small contribution to any evangelistic purpose. Its contribution to Christian history is of little significance. It has an important apologetic function in relation to the author's ongoing defence of Paul. Nevertheless, its disproportion to the rest of Acts demands explanation. Admittedly, it would have been enjoyed by audiences, but not for the amount of detail of geography, winds, and nautical practice Luke provides. ${ }^{94}$ It is easier to account for, however, if it comes from someone for whom the impression of the voyage was recent, personal, and profound. But, as Hemer suggests, the impression of the voyage would surely have faded as the cataclysmic events of the following decade unfolded. The amount of vivid detail betrays the recentness of the recollection:

It is our contention that these inconsequential details are hard to explain except as vivid experiences recalled at no great distance in time. Even an eyewitness writing years later would be likely to shape and smooth his narrative to fit more considered, selective criteria of significance. ${ }^{95}$

In support of a late date, it might be argued that the author was silent about Paul's death, because he (the author) had provided him with a form of death and resurrection in the shipwreck. ${ }^{96}$ However, the attention given to Paul's shipwreck experience points rather to the author having no other account of Paul's death. Certainly, the story is part of the author's apology for Paul: through a life-threatening ordeal, he stands tall in comparison with all around him; God brings him safe to Rome. But

93 It is not without any theological purpose. It supports the contention that God was with Paul as he carried out a God-ordained mission. However, this point has been made in various ways through Acts and hardly requires a story as lengthy as the voyage. Some further explanation is called for.

94 The story is told with some restraint. An author whose main intention was storytelling might dwell on the heaving waves, howling gale, terror of the passengers and crew, etc.

95 Hemer, Acts, 389. The argument holds for an author making later use of a written account of the voyage.

96 Parsons, Acts, 360 thinks the shipwreck functions as a 'symbolic' death and resurrection account for Paul, though he does not connect this with the short ending of Acts. See also Pervo, Acts, 652-76 and Carl N. Toney, 'Paul in Acts: The Prophetic Portrait of Paul' in Issues in Luke-Acts, ed. S. A. Adams and M. Pahl (Piscataway: Gorgias, 2012): 259-260. 
this hardly compares to an imperial trial or martyrdom, if the author had knowledge of them. ${ }^{97}$

\section{Conclusion}

The case for dating Acts in the early 60 s has been argued by others. This paper offers two additions to the case for a date in the early $60 \mathrm{~s}$ and a restatement of a third. First, the manner in which Luke has portrayed salvation in terms of Israel's national hope would have been dangerous for the author and recipients of the book any time after the outbreak of hostilities with Rome, and well into the second century. Second, the viewpoint of Acts presupposes a church whose Jewishness is taken for granted, with justification needed for Gentiles to be admitted. This was the situation before AD 70, not afterwards. Third, the prominence given to the voyage to Rome and the vividness of detail in the account indicate an author at work prior to the extraordinary disruptions of the following decade.

I do not pretend to have closed the discussion; there are a multitude of considerations. My wish is that these three should be given their place.

${ }^{97}$ Of course, this now begs a discussion of the purpose of the conclusion of Acts, including both the voyage and the final chapter, but this is beyond the scope of this article. 